\title{
Developing a Slow-release Nitrogen Fertilizer from Organic Sources: II. Using Poultry Feathers
}

\author{
Jong-Myung Choi ${ }^{1}$ and Paul V. Nelson ${ }^{2}$ \\ Department of Horticultural Science, North Carolina State University, Raleigh, NC 27695-7609 \\ Additional index words. disulfide bonds, formaldehyde, mineralization, peptide bonds, poultry by-products
}

\begin{abstract}
The structure of feather keratin protein was modified in attempts to develop a slow-release $\mathbf{N}$ fertilizer of 12 weeks duration or longer by steam hydrolysis to break disulfide bonds, enzymatic hydrolysis with Bacillus licheniformis (Weigmann) to break polypeptide bonds, and steam hydrolysis (autoclaving) to hasten mineralization followed by crosslinking of the protein by a formaldehyde reaction to control the increased rate of mineralization. Release of $\mathrm{N}$ in potting substrate within elution columns from ground, but otherwise untreated, raw feathers occurred mainly during the first 5 weeks with a much smaller release occurring from weeks 8 to 12. Steam hydrolysis resulted in an increase of $\mathrm{N}$ during the first 5 weeks and a decrease during weeks 8 to 11. Cumulative $N$ release over 11 weeks increased from $12 \%$ in raw feathers to $52 \%$ for feathers steam hydrolyzed for 90 minutes. This favored an immediately available fertilizer but not a slowrelease fertilizer. Microbial hydrolysis with $B$. licheniformis resulted in a modest reduction of $\mathrm{N}$ release during the first 5 weeks and a small increase during weeks 8 to 11. Both shifts, while not desirable for an immediately available fertilizer, enhanced the slow-release fertilizer potential of feathers but not sufficiently to result in a useful product. Steam hydrolyzed feathers cross-linked with quantities of formaldehyde equal to $5 \%$ and $10 \%$ of the feather weight released less $\mathrm{N}$ during the first 5 weeks, more during weeks 6 and 7, and less during weeks 9 to 12 compared to raw feathers. The first two shifts were favorable for a slow-release fertilizer while the third was not.
\end{abstract}

Many organic materials from different animal sources such as manure (Post, 1956), hoof and horn, blood meal, and blood and bone (Handrek and Black, 1984) have been evaluated as $\mathrm{N}$ fertilizers for greenhouse applications. However, Bunt (1988) indicated that $70 \%$ of the $\mathrm{N}$ was released within 30 days under greenhouse conditions. Williams and Nelson (1992) reported similar results. They evaluated eight organic $\mathrm{N}$ sources for mineralization (release of nutrients in plant available forms) in greenhouse chrysanthemum [Dendranthema $\times$ grandiflorum (Ramat.) Kitamura] and found durations of $\mathrm{N}$ release to be 6 to 7 weeks in all organic materials except poultry feathers. Release of $\mathrm{N}$ from feathers was too slow to be of use as a fertilizer.

Feathers are produced in huge quantities as a waste material of the poultry processing industry. Since $90 \%$ of feather dry weight consists of crude keratin protein, and feathers as a whole contain about 15\% N (Papadopoulos et al., 1985, 1986), they have a strong potential to be used as a slow-release $\mathrm{N}$ fertilizer in the greenhouse and nursery industries. However, practical use of feather keratin is currently limited to the animal feed industry where structural modifications are made in polypeptide bonds and disulfide bonds to increase digestibility.

Mineralization of organic $\mathrm{N}$ under soil conditions refers to release of $\mathrm{NH}_{4}$ from proteins, amino acids, and nucleic acids via degradative reaction initiated by soil microorganisms (Paul and Clark, 1989). Slow release of $\mathrm{N}$ from feather keratin indicates that soil microorganisms can not readily cleave the keratin structure.

Received for publication 10 Apr. 1995. Accepted for publication 26 Mar. 1996 This research was funded in part by Sun Gro Horticulture, Inc., Bellevue, Wash., and the North Carolina Agricultural Research Service (NCARS), Raleigh. Use of trade names in this publication does not imply endorsement by the NCARS of the products named nor criticism of similar ones not mentioned. We gratefully acknowledge J.D. Garlich and A.G. Wollum for helpful discussion in planning and interpreting this research and J.C.H. Shih for preparation of the bacterium culture solution. From a dissertation submitted by J.-M.C. in partial fulfillment of the PhD requirements. The cost of publishing this paper was defrayed in part by the payment of page charges. Under postal regulations, this paper therefore must be hereby marked advertisement solely to indicate this fact.

${ }^{1}$ Graduate research assistant

${ }^{2}$ Professor.
Therefore, if keratin structure was modified by the cleavage of specific bonds, the mineralization rate would increase. The cloven feather structure would reduce chemical barriers by providing more reactive sites for microbial enzymes and would reduce physical barriers by providing more surface area for microbial breakdown.

Modification of feather keratin structure in the animal feed industry follows two main approaches: A) steam hydrolysis, which breaks disulfide bridges (McCasland and Richardson, 1967; Morris and Balloun, 1973), and B) enzymatic action of Bacillus licheniformis (Williams et al., 1990) and Streptomyces fradiae (Waksman and Curtis) Waksman and Henrico (Elmayergi and Smith, 1971) that cleaves polypeptide bonds. An additional possibility is to use carbonyl compounds such as aldehydes that react very readily and reversely with amino groups of proteins to form Schiff's bases (Wong, 1991). After steam hydrolyzing feathers to break disulfide bonds and thereby hasten mineralization, new cross-links could be formed in keratin by reaction with formaldehyde. Many of the new aminobonds would be unnatural and therefore resistant to the proteolytic enzymes of mineralizing microbes (Milligan and Holt, 1977; Seltzer, 1973).

Therefore, the objectives of this research were to modify disulfide bonds and polypeptide bonds in feather keratin by heat hydrolysis, microbial enzyme attack, and heat hydrolysis coupled with formaldehyde cross-linking of keratin and to determine the effects of these modifications on mineralization of $\mathrm{N}$ from feather keratin in a potting substrate. It was hoped that these modifications would lead to a slow-release fertilizer with a continually increasing rate of $\mathrm{N}$ release over a period of 12 weeks or longer to match the $\mathrm{N}$ requirement of many container grown crops.

\section{Materials and Methods}

Preparation of raw feathers. White feathers of broiler chickens were obtained from a local poultry processing plant soon after plucking. They were freed of foreign matter, cleaned with tap water, dried $3 \mathrm{~d}$ in a forced draft oven at $60{ }^{\circ} \mathrm{C}$, and stored for subsequent use. In each of the following experiments a raw feather 
Table 1. Description of treatments and the final total $\mathrm{N}$ concentrations in resulting feather products in Expt. 3.

\begin{tabular}{lcr}
\hline \hline $\begin{array}{l}\text { Formaldehyde }^{\mathrm{z}} \\
(\%)\end{array}$ & $\begin{array}{c}\text { Feathers }^{\mathrm{y}} \\
(\%)\end{array}$ & $\begin{array}{c}\mathrm{N} \\
\text { content }\end{array}$ \\
\hline 0 & Raw & 14.7 \\
0 & Hydrolyzed & 15.3 \\
0.005 & Hydrolyzed & 12.3 \\
0.01 & Hydrolyzed & 12.3 \\
0.05 & Hydrolyzed & 12.0 \\
0.1 & Hydrolyzed & 12.2 \\
0.5 & Hydrolyzed & 11.5 \\
1.0 & Hydrolyzed & 11.8 \\
5.0 & Hydrolyzed & 11.4 \\
10.0 & Hydrolyzed & 11.5 \\
$\mathrm{LSD}_{0.05}$ & & 0.55 \\
\hline
\end{tabular}

control treatment was included. Raw feathers consisted of washed and dried feathers ground in a Wiley mill to a particle size $\leq 1 \mathrm{~mm}$.

Preparation of steam hydrolysed feathers. Distilled water was added at the rate of $5 \mathrm{~mL}$ per $10 \mathrm{~g}$ whole, dry feathers. These feathers were then steam hydrolysed in Expt. 1 for 15, 45, or 90 min at a temperature of $135^{\circ} \mathrm{C}$ and a pressure of $207 \mathrm{kPa}$ to produce easily degradable $\mathrm{N}$ products. Timing of steam hydrolysis began when the specified temperature and pressure levels were reached. Then, feathers were dried overnight at $70^{\circ} \mathrm{C}$ and ground to a particle size $\leq 1 \mathrm{~mm}$. These final products were designated as hydrolyzed feathers.

Preparation of microbial hydrolysed feathers. Whole feathers were microbially hydrolysed with a culture of $B$. licheniformis $\left(10^{8}\right.$ cells $/ \mathrm{mL}$ of culture solution) for 0,24 , 48,84 , or $120 \mathrm{~h}$ at $50{ }^{\circ} \mathrm{C}$ in Expt. 2. The ratio of feathers to $B$. licheniformis culture solution was 1:1 (w/w). After hydrolysis, feathers were dried for $2 \mathrm{~d}$ at $70{ }^{\circ} \mathrm{C}$ and ground to a particle size $\leq 1$ $\mathrm{mm}$. These products were designated as microbial hydrolysed feathers.

Preparation of formaldehyde treated feathers. Feathers were steam hydrolysed in Expt. 3, as previously described, for $150 \mathrm{~min}$ and were then reacted with weights of formaldehyde (a.i.) equal to $0.1 \%, 0.5 \%, 1.0 \%, 5.0 \%$, or $10.0 \%$ of the dry weight of the steam hydrolyzed feathers. The formaldehyde reaction entailed addition of 60 $\mathrm{mL}$ distilled water to $30 \mathrm{~g}$ steam hydrolysed feathers resulting in a thick slurry. Formaldehyde was added to these slurries and then $3.75 \mathrm{~g}$ $\mathrm{H}_{3} \mathrm{PO}_{4}$ was added to lower the $\mathrm{pH}$ level to about 1.5. The slurries were cooled to ambient temperature. The reaction
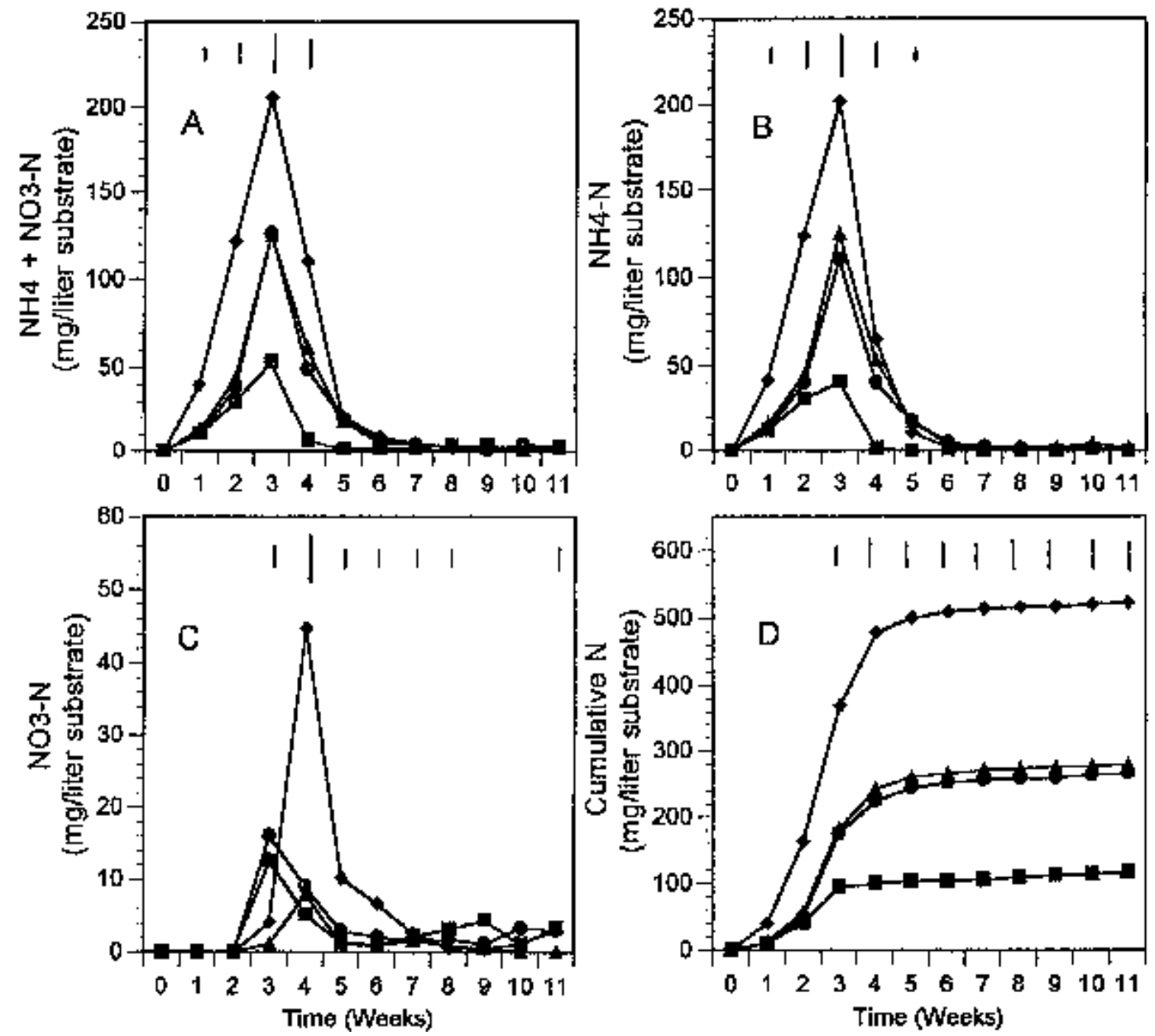
earlier paper in this series (Choi and Nelson, 1996). In addition to the treatment columns in each experiment, background columns were set up with substrate but no feather products. These columns were eluted to determine forms and quantities of $\mathrm{N}$ released and these values were subtracted from all treatment values.

Experimental design and data analysis. The elution columns in each experiment were arranged in a randomized complete block design with three replications. One column was used in each plot. The standard error for all treatments was determined within each week for data from column leachate analysis using the CoStat program (CoHort Software, Berkeley, Calif.). Total N concentration data from analysis of the feather products in Expt. 3 were subjected to analysis of variance procedures and means were separated by the LSD test.

\section{Results and Discussion}

Average total $\mathrm{N}$ concentration in steam hydrolyzed (Expt. 1) and microbially hydrolyzed (Expt. 2) feathers (data not presented) was $14.7 \%$ and did not differ among treatments. The $\mathrm{N}$ concentrations of formaldehyde-treated feather products in Expt. 3 (Table 1) were lower in the formaldehyde treatments than in the raw feathers and hydrolyzed feathers. This was due to dilution effects of reactants and titrant used in the formaldehyde reaction.

Experiment 1. Steam hydrolyzed feathers. Most N released from raw feathers occurred during weeks 1 through 3 (Fig. 1A). Steam hydrolysis of feathers for 15 and 45 min resulted in similar increases in the release of $\mathrm{N}$ during weeks 1 through 5 compared to raw feathers. Steam hydrolysis for 90 min resulted in a further increase during the same time period. The increased $\mathrm{N}$ release was probably due to cleavage of disulfide bonds which rendered the feathers more susceptible to microbial degradation in the substrate (Aderibigbe and Church, 1983; Papadopoulos et al., 1986). The cumulative percentages of the total amount of $\mathrm{N}$ applied to the column substrates that were released over 11 weeks from raw feathers, and $15 \mathrm{~min}$, and $90 \mathrm{~min}$ hydrolyzed feathers were $12 \%$, $27 \%$, and $52 \%$, respectively (Fig. 1D). The increases in $\mathrm{N}$ release caused by steam hydrolysis were not favorable for purposes of a slow-release fertilizer. All of the increased release occurred during the first 5 weeks when an increase was not desired and none during the last 6 weeks where the release should have been highest. These changes were highly desirable, however, for the purposes of an immediately available fertilizer. Longer steam hydrolysis times might
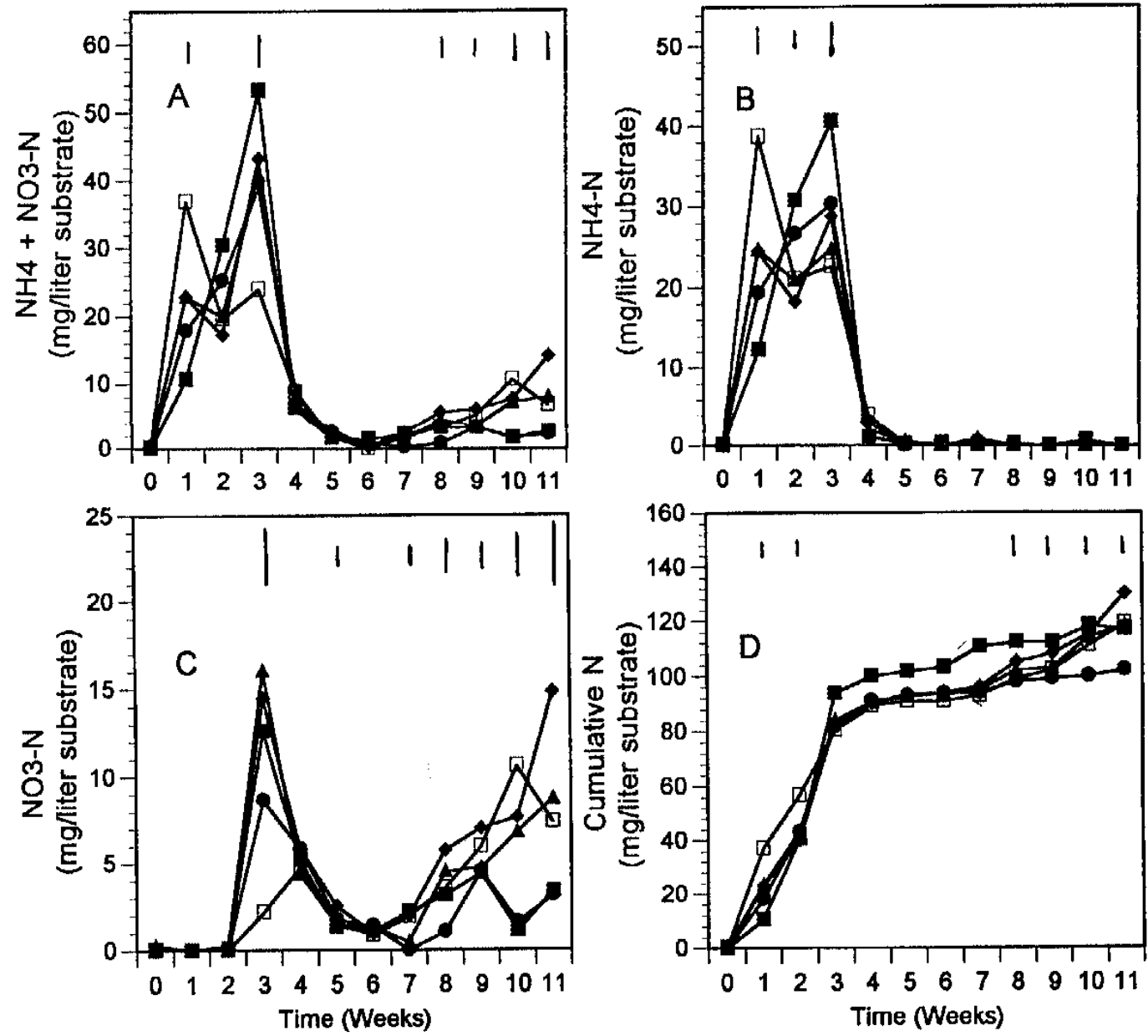

serve well for this latter objective to increase $\mathrm{N}$ mineralization above the $52 \%$ level achieved.

Experiment 2. Microbially hydrolysed feathers. The effect of microbial hydrolysis with $B$. licheniformis during the first 5 weeks was a shift toward earlier release of $\mathrm{N}$. As the time of microbial hydrolysis increased the quantity of $\mathrm{N}$ released during the first week increased proportionately while the amount released during weeks 2 and 3 decreased (Fig. 2 A and B). The total cumulative amounts of $\mathrm{N}$ released by the end of week 5 (Fig. 2D) from the various microbial hydrolysis treatments did not differ from each other and were only slightly lower than in the raw feather treatment. Overall, there was no advantage gained during the first 5 weeks toward the requirements for a slow-release fertilizer. Increased release during week 1 constituted a disadvantage while reduced cumulative release over the first 5 weeks provided a small advantage. The main advantage of microbial hydrolysis occurred in the release pattern of total $\mathrm{N}$ during weeks 8 through 11 (Fig. 2A). Feathers microbial hydrolysed for 48, 84, and $120 \mathrm{~h}$ released more $\mathrm{N}$ than raw feathers in that period. The largest release of $\mathrm{N}$ at

Fig. 2. Weekly quantities of $\mathrm{NH}_{4}-\mathrm{N}+\mathrm{NO}_{3}-\mathrm{N}(\mathbf{A}), \mathrm{NH}_{4}-\mathrm{N}(\mathbf{B})$, and $\mathrm{NO}_{3}-\mathrm{N}(\mathbf{C})$ released into the eluent and cumulative release of $\mathrm{NH}_{4}-\mathrm{N}+\mathrm{NO}_{3}-\mathrm{N}$ (D) from columns containing substrate with feathers hydrolyzed for various lengths of time with $B$. licheniformis in Expt. 2. Each feather product was incorporated at a rate sufficient to supply $1 \mathrm{~g} \mathrm{~N} / \mathrm{L}$ ofsubstrate. Points represent mean of three replications. Vertical bars represent $1 \mathrm{SE}$ among weekly treatments $(\mathbf{\square}=$ substrate with raw feathers, $=$ substrate with 24 h hydrolyzed feathers, $\boldsymbol{\Delta}=$ substrate with $48 \mathrm{~h}$ hydrolyzed feathers, $\bullet=$ substrate with 84 h hydrolyzed feathers, $\square=$ substrate with $120 \mathrm{~h}$ hydrolyzed feathers). 

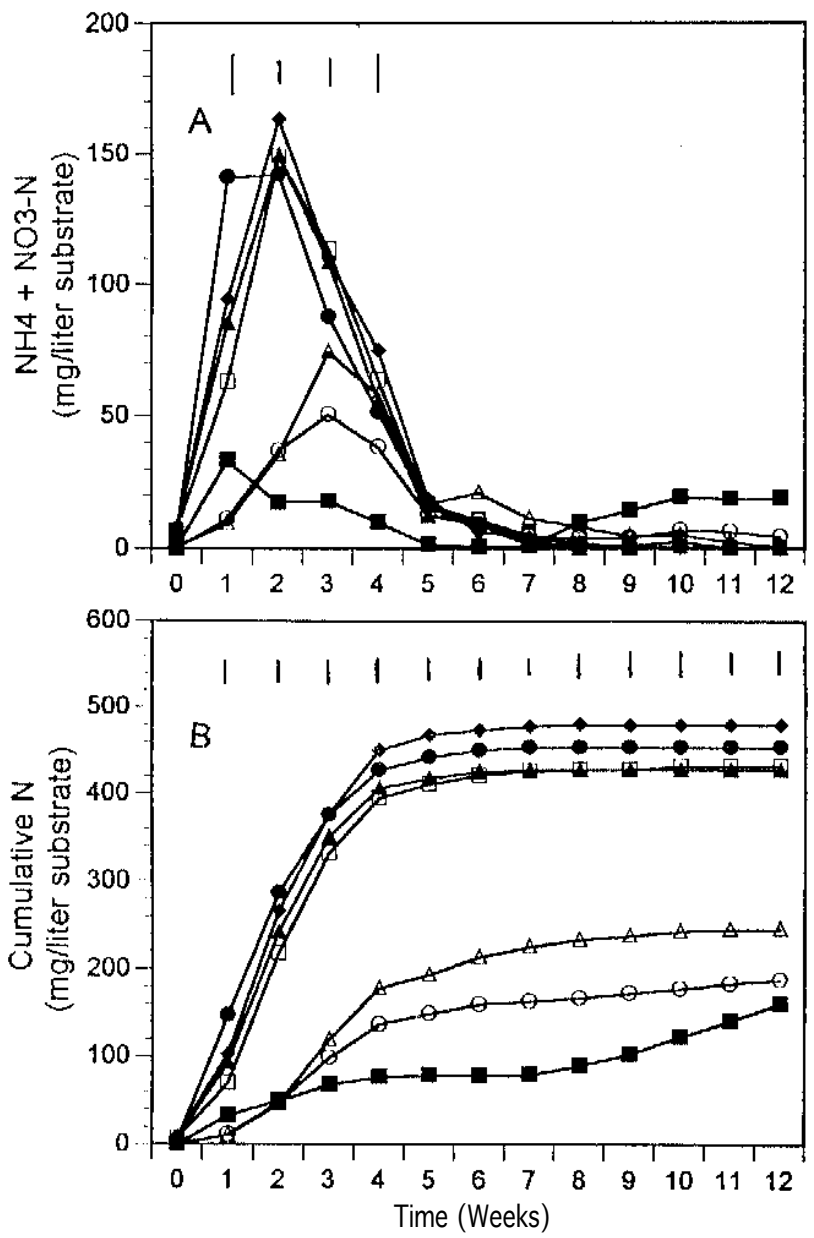

Fig. 3. Weekly quantities of $\mathrm{NH}_{4}-\mathrm{N}+\mathrm{NO}_{3}-\mathrm{N}$ (A) released into the eluent and cumulative release of $\mathrm{NH}_{4}-\mathrm{N}+\mathrm{NO}_{3}-\mathrm{N}(\mathbf{B})$ from columns containing substrate with steam hydrolyzed feathers subsequently reacted with various amounts of formaldehyde, expressed as a weight percentage of feathers, in Expt. 3. Each feather product was incorporated at a rate sufficient to supply $1 \mathrm{~g} \mathrm{~N} / \mathrm{L}$ of substrate. Points represent mean of three replications. Vertical bars represent 1 SE among weekly treatments $(\boldsymbol{\square}=$ raw feathers, $\boldsymbol{\Theta}=2.5 \mathrm{~h}$ steam hydrolyzed feathers, $\boldsymbol{\Lambda}=$ hydrolyzed feathers reacted with $0.1 \%$ formaldehyde, $\bullet=$ hydrolyzed feathers reacted with $0.5 \%$ formaldehyde, $\square=$ hydrolyzed feathers reacted with $1.0 \%$ formaldehyde, $\bigcirc=$ hydrolyzed feathers reacted with $5.0 \%$ formaldehyde, $\Delta=$ hydrolyzed feathers reacted with $10.0 \%$ formaldehyde).

week 11 occurred from $84 \mathrm{~h}$ hydrolysed feathers. Feathers microbially hydrolysed for $84 \mathrm{~h}$ released $4.4 \%$ of their $\mathrm{N}$ during weeks 8 through 11 while raw feathers released $2.6 \%$ of their $\mathrm{N}$ in the same period. The gain from $84 \mathrm{~h}$ of microbial hydrolysis over raw feathers was only $1.8 \%$ of the $1000 \mathrm{mg}$ of feather $\mathrm{N}$ applied to each column (Fig. 2D).

Comparison of the $\mathrm{NH}_{4}$ release curves in Fig. 2B with the $\mathrm{NO}_{3}$ release curves in Fig. $2 \mathrm{C}$ reveals a delay in the peak of $\mathrm{NO}_{3}$ release. This was likely due to oxidation of $\mathrm{NH}_{4}$ to $\mathrm{NO}_{3}$ by nitrifying bacteria (Paul and Clark, 1989). The delay can be accounted for by the time required for the nitrifying bacteria populations to build up in response to the initial occurrence of $\mathrm{NH}_{4}$ in the substrate.

Microbial hydrolysis of whole feathers with $B$. licheniformis brought about desirable reductions during the first 5 week period and increases during the 8- to 11 -week period of $\mathrm{N}$ release. The shifts, however, were not sufficiently large to warrant use of microbial hydrolysis, as conducted in this experiment, for developing slow-release fertilizer from feathers. Further studies with keratinase active microorganisms are warranted and treatment of ground rather than whole feathers should be tested.

Experiment 3. Formaldehyde treated feathers. Release of $\mathrm{N}$ for slow-release fertilizer purposes was best, although not completely satisfactory, from raw feathers (Fig. 3A). There was a period of N release through the first four weeks, followed by little release during weeks 4 through 6 , and a second period of release during weeks 7 through 12 . The slope of the cumulative curve for $\mathrm{N}$ release from raw feathers (Fig. 3B) came closer to matching the continually increasing slope sought for a slow-release fertilizer than any other treatment. Feathers steam hydrolyzed for $150 \mathrm{~min}$ released a larger quantity of $\mathrm{N}$ during the first 6 weeks than raw feathers and nearly no $\mathrm{N}$ thereafter (Fig. 3A). This was more suitable for an immediately available fertilizer but less desirable for a slow-release fertilizer than raw feathers since the cumulative release of $\mathrm{N}$ was increased from $16 \%$ in raw feathers to $45 \%$ in hydrolyzed feathers (Fig. 3B).

Steam hydrolyzed feathers reacted with $0.1 \%, 0.5 \%$, and $1.0 \%$ formaldehyde had similar $\mathrm{N}$ release patterns to feathers that were only steam hydrolyzed (Fig. 3A). Steam hydrolyzed feathers reacted with $5 \%$ and $10 \%$ formaldehyde released less $\mathrm{N}$ during the first 4 weeks than feathers only hydrolyzed and a similar low amount in subsequent weeks, thus, these treatments were inferior to hydrolyzed feathers for both types of fertilizers. Hydrolyzed feathers reacted with $0.005 \%, 0.01 \%$, and $0.05 \%$ formaldehyde had a virtually identical $\mathrm{N}$ release pattern to feathers that were only steam hydrolyzed (data not shown). Overall, cross-linking of steam hydrolyzed feather keratin with formaldehyde offered no advantages for an immediately available fertilizer over feathers hydrolyzed only because total $\mathrm{N}$ release was similar and rendered feathers less desirable for slow-release fertilizer than raw feathers due to the lower $\mathrm{N}$ release during weeks 8 through 12 .

The release of $\mathrm{PO}_{4}-\mathrm{P}$ and $\mathrm{Ca}$ into the eluents followed almost identical patterns and quantitative levels to those in Fig 3 of the previous paper (Choi and Nelson, 1996) (data not shown). Again, the sources appeared to be the $\mathrm{H}_{3} \mathrm{PO}_{4}$ and $\mathrm{CaO}$ used in the formaldehyde reaction. Most $\mathrm{PO}_{4}$ was present at time 0 . Little $\mathrm{PO}_{4}$ was released during weeks 1 through 5 , but during weeks 6 through 12 there was an increase in $\mathrm{PO}_{4}$ release in the treatments where $\mathrm{H}_{3} \mathrm{PO}_{4}$ was used. Calcium release declined over time. The level of $\mathrm{Ca}$ release related well with the amount of formaldehyde used in the reaction with feathers. Again, this suggests that less supplemental $\mathrm{PO}_{4}$ and $\mathrm{Ca}$ would be required if a crop were fertilized with a formaldehyde processed feather product.

In summary, steam hydrolysis of feathers resulted in a four fold increase in $\mathrm{N}$ release which was good for an immediate release fertilizer but did not add to the 12-week profile of slow $\mathrm{N}$ release that was sought since the increased release occurred during the first 5 weeks. Cross linking of amino groups in the feather protein with formaldehyde after steam hydrolysis did not improve the slowrelease properties of feathers either. The one procedure that was successful in increasing the slow-release property of feathers was microbial hydrolysis with $B$. licheniformis which increased $\mathrm{N}$ release during the 8 - through 11 -week period. While the increase was not sufficient to yield a commercial product, it indicated that further investigation of microbial hydrolysis was warranted.

\section{Literature Cited}

Aderibigbe, A.O. and D.C. Church. 1983. Feather and hair meals for ruminants. 1. Effect of degree of processing on utilization of feather meal. J. Animal Sci. 56:1198-1207. 
Bunt, A.C. 1988. Media and mixes for container-grown plants. Unwin Hyman, London.

Choi, J.M. and P.V. Nelson. 1996. Developing a slow-release nitrogen fertilizer from organic sources: I. Using nonviable bacteria. J. Amer. Soc. Hort. Sci. 121:629-633.

Eastin, E.F. 1978. Total nitrogen determination for plant material containing nitrate. Anal. Biochem. 85:591-594.

Elmayergi, H.H. and R.E. Smith. 1971. Influence of growth of Streptomyces fradiae on pepsin- $\mathrm{HCl}$ digestibility and methionine content of feather meal. Can. J. Microbiol. 17:1067-1072.

Handreck, K.A. and N.D. Black. 1984. Growing media for ornamental plants and turf. New South Wales Univ. Press. Kensington, Australia. McCasland, W.E. and L.R. Richardson. 1967. Methods for determining the nutritive value of feather meal. Poultry Sci. 46:1231-1236.

Milligan, B. and L.A. Holt. 1977. The complete enzymic hydrolysis of cross-linked proteins, p. 277-284. In: M. Friedman (ed.). Protein crosslinking. Plenum Press, New York.

Morris, W.C. and S.L. Balloun. 1973. Evaluation of five differently processed feathermeals by nitrogen retention, net protein values, xanthine dehydrogenase activity and chemical analysis. Poultry Sci. 52:1075-1084.

Papadopoulos, M.C., A.R. EL-boushy, and A.E.Roodbeen. 1985. The effect of varying autoclaving conditions and added sodium hydroxide on amino acid content and nitrogen characteristics of feather meal. J. Sci. Food Agri. 36:1219-1226.

Papadopoulos, M.C., A.R. EL-boushy, A.E. Roodbeen, and E.H. Ketelars. 1986. Effects of processing time and moisture content on amino acid composition and nitrogen characteristics of feather meal. Animal Feed Sci. Tech. 14:279-290.

Paul, E.A. and F.E. Clark. 1989. Soil microbiology and biochemistry. Academic Press, New York.

Post, K. 1956. Florist crop production and marketing. Orange Judd Pub. Co., Inc., New York.

Seltzer, W. 1973. Treatment of animal and fowl litter and feces. U.S. Patent 3,743,496.

Williams, C.M., C.G. Lee, J.D. Garlich, and J.C.H. Shih. 1990. Evaluation of a bacterial feather fermentation product, feather-lysate, as a feed protein. Poultry Sci. 70:85-94.

Williams, K.A. and P.V. Nelson. 1992. Low, controlled nutrient availability provided by organic materials for chrysanthemum. J. Amer. Soc. Hort. Sci. 117:422-429.

Wong, S.S. 1991. Chemistry of protein conjugation and cross-linking. CRC Press, New York. 